\title{
"Muito Prazer... Eis a Adolescência": Relato de uma Experiência Interativa
}

\author{
Lourenço, Benito \\ Unidade de Adolescentes do Instituto da Criança do HCFMUSP — benitol@uol.com.br
}

\begin{abstract}
Introdução a cultura leiga produziu uma crença de que a adolescência é, por si, um período de insegurança, rebeldia e impulsividade ou, de certa forma, um período problemático do desenvolvimento. Profissionais de saúde e educadores podem, entretanto, refletir, de forma menos estereotipada sobre as características específicas desse momento da vida que, em última análise, os ajudariam a desenvolver uma leitura mais singular sobre os "problemas" emergentes e uma condução mais específica nas ações de promoção de saúde para essa faixa etária. Objetivos uma atividade denominada "Experiência Interativa: Muito Prazer... eis a adolescência" foi concebida e apresentada para profissionais, objetivando o treinamento e a sensibilização sobre temas relacionados às características e transformações biopsicossociais da adolescência. Método Trata-se de uma aula com uma formatação interativa, conduzida por um médico de adolescentes, e que tem sua exposição entremeada por participações de adolescentes previamente treinados, que seguem um roteiro, com intervenções artísticas, como pequenas cenas dramáticas e esquetes cômicos que ilustram os assuntos que estão sendo apresentados. a partir de exemplos retirados das experiências cotidianas, imagens e músicas utilizadas como elementos disparadores, promove-se um gradativo conhecimento e reflexão sobre a adolescência. Tudo é realizado em um espaço cênico, com recursos de som e luz, que conferem à atividade um caráter artístico de uma apresentação teatral. Resultados: no período de 2005 à 2013 a atividade foi apresentada em 58 ocasiões, para públicos diversos: alunos de graduação (Medicina e Psicologia), eventos de treinamento em Saúde da Família e plateias multiprofissionais (educadores e profissionais da área de Saúde). Conclusões e Reflexões 1. a arte como elemento de educação e aprendizado: na busca da iniovação pedagógica, a ideia de apresentar conceitos teóricos sobre a adolescência, de forma interativa, com adolescentes e envolvendo princípios artísticos em sua concepção e formatação, pode aproximar e sensibilizar o expectador de uma forma bem peculiar. por meio da arte é possível desenvolver a percepção e a imaginação, apreender a realidade do ambiente, estimular a capacidade crítica, permitindo ao indivíduo desenvolver a criatividade de maneira a mudar a realidade que foi analisada. 2. a aplicação prática do conceito de protagonismo juvenil: os próprios adolescentes colaboram na concepção da apresentação. Adolescentes participam do processo de ensinar aos profissionais como lidar com as situações particulares desse momento. Além disso, com a expertise que lhes é própria, esse processo se faz de uma forma mais natural e espontânea. 3. a ressignificação da adolescência: durante o processo criador, ao interpor realidade, imaginação, emoção e cognição, os adolescentes envolvem-se em reconstruções, reelaborações e descobertas que permitem o entendimento sobre o momento de vida que estão passando.
\end{abstract}

Lourenço, Benito. "Muito Prazer... Eis a Adolescência": Relato de uma Experiência Interativa. In: Anais do

Congresso Internacional de Humanidades \& Humanização em Saúde [= Blucher Medical Proceedings, num.2, vol.1]. São Paulo: Editora Blucher, 2014. ISSN 2357-7282

DOI 10.5151/medpro-cihhs-10478 